\title{
STUDI KADUNGAN IODIUM DALAM RUMPUT LAUT EUCHEUMA COTTONII DIPERAIAN KEI KECIL
}

\author{
R. Untailawan ${ }^{*}$, Y. T. Male $^{2}$, Y. H. Dulanlebit ${ }^{1}$ \\ ${ }^{1}$ Program Studi Pendidikan Kimia, FKIP Universitas Pattimura Ambon \\ ${ }^{2}$ Jurusan Kimia, FMIPA Universitas Pattimura Ambon \\ romelos.untailawan@yahoo.co.id
}

\begin{abstract}
ABSTRAK. Iodium berperan penting bagi pertumbuhan manusia. Kekurangan asupan iodium dapat menimbulkan berbagai penyakit. Kebutuhan asupan iodium dapat dipenuhi dengan mengkonsumsi pangan kaya iodium. Rumput laut eucheuma cottonii diketahui miliki kandungan iodium yang tinggi. Perarian Kei Kecil merupakan salah satu sentra pembudidayaan rumput laut eucheuma cottonii dikawasan timur Indonesai. Kandungan iodium dalam rumput laut sangat dipengaruhi oleh tempat pembudidayaannya. Penelitian ini dilakukan untuk memperoleh informasi tentang kandungan iodium dalam rumput laut eucheuma cottonii diperairan Kei Kecil. Penentuan kandungan iodium menggunakan metode spektrofotometri ultraviolet dengan mengoptimasi konsentrasi $\mathrm{H}_{3} \mathrm{PO}_{4}$ dan $\mathrm{KI}$. Hasil penelitian menunjukan rata-rata kandungan iodium dalam rumput laut eucheuma cottonii yaitu 29,96 $\mu \mathrm{g} / \mathrm{g}$. Penelitian dilakukan pada $\lambda_{\text {maks }} 351 \mathrm{~nm}$ dengan konsentrasi optimum $\mathrm{H}_{3} \mathrm{PO}_{4}$ 0,6 $\mathrm{M}$ dan $\mathrm{KI} 0,06 \mathrm{M}$.
\end{abstract}

Kata kunci: Eucheuma cottonii, iodium, spektrofotometri ultraviolet, Kei Kecil

\section{Pendahuluan}

Pada bagian ini memuat berbagai alasan tentang urgensi penelitian, penelitian-penelitian sebelumnya serta gagasan yang diajukan. Pastikan bahwa ide paper anda bukan plagiarisme. Segala bentuk plagiarisme adalah suatu kejahatan (Sze, 2012).

Iodium merupakan salah satu nutrisi penting bagi pertumbuhan manusia. Setiap hari manusia membutuhkan 100-150 $\mu \mathrm{g}$ asupan iodium. Kekurangan asupan iodium dalam waktu yang lama dapat menyebabkan kretinisme, gondok, penurunan tingkat kecerdasan, serta kematian pada janin (Adriani dan Wijadmadi, 2012). Ganguan akibat kekurangan iodium ini kemudian dikenal sebagai Ganguan Akibat Kekurangan Iodium (GAKI).

Pencegahan GAKI dapat dilakukan dengan mengkonsumsi pangan yang kaya akan kandungan iodium. Pangan laut diketahui memiliki kandungan iodium yang lebih tinggi dari pangan yang berasal dari daratan, sehingga pangan laut dapat dijadikan sebagai sumber asupan iodium untuk mencegah terjadinya GAKI (Gunardi dkk, 1999). Salah satu pangan laut yang dapat dijadikan sebagai sumber asupan iodium adalah rumput laut jenis eucheuma cottonii.

Matanjun dkk (2009) telah melakukan penelitian terhadap kandungan nutrisi dalam rumput laut diperairan Kalimatan Utara, hasil penelitian menunjukan bahwa kandungan iodium dalam rumput laut eucheuma cottoni (9 $\mu \mathrm{g} / \mathrm{g})$ lebih tinggi dibandingkan dengan rumput laut sargassum polycystum $(7,66 \mu \mathrm{g} / \mathrm{g})$ dan caulerpa lentillifera $(4,78 \mu \mathrm{g} / \mathrm{g})$. Nutrisi yang terkandung dalam rumput laut selain dipengaruhi oleh jenis, juga sangat dipengaruhi oleh tempat pembudidayaan.

Rumput laut e. cottoni merupakan rumput laut yang paling banyak dibudidayakan di Indonesia, karena perawatan yang mudah dan masa panen yang relatif cepat. Salah satu sentra budiday rumput laut e. cottoni di Kawasan Timur Indonesia, yaitu pada perairan Kei Kecil - Maluku. Pada penelitian ini akan dilakukan studi terkait kandungan iodium pada rumput laut e. cottoni yang dibudidayakan di perairan Kei Kecil.

\section{Metode}

Analisis kandungan iodium $\left(\mathrm{I}_{2}\right)$ dalam rumput laut $e$. cottonii dilakukan dengan menentukan kandungan kalium iodat $\left(\mathrm{KIO}_{3}\right)$ sebagai iodium dalam rumput laut secara spektrofotometri ultraviolet. Iodium yang terbentuk dari reaksi $\mathrm{IO}_{3}{ }^{-}$dengan $\mathrm{I}^{-}$dalam suasana asam $\left(\mathrm{H}^{+}\right)$, akan bereaksi secara berlebih dengan $\mathrm{I}^{-}$sehingga membentuk 
ion triiodida $\left(\mathrm{I}_{3}{ }^{-}\right)$. Ion triiodida kemudian di ukur serapanya pada spektrofotometer ultraviolet (Dulanlebit dan Hattu, 2009 ; Jung dkk, 2014)

$$
\begin{gathered}
\mathrm{IO}_{3}^{-}+5 \mathrm{I}^{-}+6 \mathrm{H}^{+} \underset{3 \mathrm{I}_{2}}{\rightleftarrows}+3 \mathrm{H}_{2} \mathrm{O} \\
\mathrm{I}_{2}+\mathrm{I}^{-}
\end{gathered}
$$

\subsection{Peralatan dan Bahan}

Bahan-bahan yang digunakan dalam penelitian ini adalah rumput laut e. cottonii yang diperoleh dari petani budidaya rumput laut di perairan Kei Kecil, $\mathrm{KIO}_{3}$ 99\% ( E. Merck), KI E. Merck (99\%), $\mathrm{H}_{3} \mathrm{PO}_{4}$ E. Merck (99\%). Alat-alat yang digunakan dalam penelitian ini adalah Spektrofotometer UV-Vis Shimadzu 1700, neraca analitik Ohaus AR2140, peralatan gelas Pyrex, hot plate Cimarec SP131320-33, termometer, dan magnetik stirrer.

\subsection{Persiapan Sampel}

Sampel penelitian merupakan rumput laut jenis e. cottoni yang diambil pada 3 (tiga) lokasi yaitu pada perairan Desa Taar, Wab, dan Ohoidertawun - Kei Kecil Maluku. Sampel yang telah dikumpulkan selanjutnya dicuci serta dikeringkan. Sampel selanjutnya dihaluskan kemudian disimpan untuk proses analisis lebih lanjut.

\subsection{Penentuan Panjang Gelombang Maksimum $\left(\lambda_{\text {maks }}\right)$}

Penentuan $\lambda_{\text {maks }}$ dilakukan dengan pengukuran ion triiodida yang terbentuk dari hasil reaksi antara $\mathrm{KIO}_{3}$ dengan KI berlebih dalam suasana asam. Kedalam beker gelas dimasukkan 5,0 mL KI 0,001 M; 5,0 $\mathrm{mL} \mathrm{H}_{3} \mathrm{PO}_{4}$ 0,1 M; dan 5,0 $\mathrm{mL} \mathrm{KIO}_{3}$ 8,0 ppm. Larutan diaduk dan diukur serapannya pada panjang gelombang $200-400 \mathrm{~nm}$.

\subsection{Optimasi Parameter Pengukuran}

Dengan cara yang sama, dilakukan optimasi larutan $\mathrm{H}_{3} \mathrm{PO}_{4}$ dan KI. Optimasi pengukuran $\mathrm{H}_{3} \mathrm{PO}_{4}$ dengan memvariasi konsentrasi $\mathrm{H}_{3} \mathrm{PO}_{4}$ 0,1 - 1,2 $\mathrm{M}$ pada konsentrasi $\mathrm{KI}$ dan $\mathrm{KIO}_{3}$ yang tetap. Optimasi pengukuran $\mathrm{KI}$ dengan memvariasi konsentrasi $\mathrm{KI} 0,008-0,09 \mathrm{M}$ pada konsentrasi $\mathrm{KIO}_{3}$ yang tetap dan konsentrasi $\mathrm{H}_{3} \mathrm{PO}_{4}$ optimum. Masing-masing variasi konsentrasi diukur serapannya pada $\lambda_{\max }$.

\subsection{Pengukuran Kadungan Iodium dalam Rumput Laut}

Timbang 1 gram sampel yang telah dihaluskan kemudian panaskan dengan campuran 50,0 mL KI dan 50,0 $\mathrm{mL} \mathrm{H}_{3} \mathrm{PO}_{4}$ (konsentrasi hasil optimasi). Pemanasan dilakukan pada suhu $100{ }^{\circ} \mathrm{C}$ selama kurang lebih 15 menit. Setelah dipanaskan, sampel disaring dan diukur serapannya pada $\lambda_{\max }$. Nilai serapan yang diperoleh dari hasil pengukuran diplotkan pada kurva kalibrasi, dan dilakukan perhitungan untuk menentukan kandungan iodium dalam sampel rumput laut.

\section{Hasil Penelitian}

\subsection{Persiapan Sampel}

Rumput laut e. cottoni yang telah diambil dari ketiga lokasi kemudian dicuci. Pencucian bertujuan untuk membersihkan rumput laut dari pengotor serta garam-garam yang menempel pada permukaan rumput laut. Proses selanjutnya, rumput laut dikeringkan dan dihaluskan. Dari proses pengeringan diketahui bahwa rata-rata kandungan air yang dimiliki oleh rumput laut e. cottoni yaitu 92\% (Tabel 1). Kandungan air yang terdapat dalam rumput laut ditekan seminimal mungkin untuk mencegah kerusakan (pembusukan) dari rumput laut sebelum dilakukan analisis.

Tabel 1. Kandungan air dalam rumput laut Eucheuma cottonii.

\begin{tabular}{cccc}
\hline Daerah Sampel & $\begin{array}{c}\text { Berat Basah } \\
\text { (gram) }\end{array}$ & $\begin{array}{c}\text { Berat Kering } \\
\text { (gram) }\end{array}$ & $\begin{array}{c}\text { Kadar air } \\
(\%)\end{array}$ \\
\hline Taar & 494,24 & $\mathbf{3 2 , 9 1}$ & $\mathbf{9 3 , 3 4}$ \\
Ohoidertawun & $\mathbf{3 4 2 , 9 3}$ & $\mathbf{2 6 , 2 6}$ & $\mathbf{9 2 , 3 4}$ \\
Wab & $\mathbf{3 4 7 , 8 4}$ & $\mathbf{3 0 , 6 6}$ & $\mathbf{9 1 , 1 9}$ \\
\hline \multicolumn{4}{c}{ Rata-rata } \\
\hline
\end{tabular}




\subsection{Penentuan Panjang Gelombang Maksimum $\left(\lambda_{\text {maks }}\right)$}

Ion triiodida $\left(\mathrm{I}_{3}{ }^{-}\right)$yang terbentuk dari reaksi reduksi $\mathrm{KIO}_{3}$ dengan kelebihan $\mathrm{KI}$ dalam suasana asam, memberikan serapan maksimum pada panjang gelombang 287,5 nm dan $351 \mathrm{~nm}$ (Gambar 1). Untuk analisis selanjutnya akan digunakan panjang gelombang $351 \mathrm{~nm}$. Digunakan panjang gelombang $351 \mathrm{~nm}$ karena pada panjang gelombang $287,5 \mathrm{~nm}$ yang merupakan puncak serapan yang paling tinggi memiliki daerah serapan yang sangat dekat dengan daerah serapan dari protein (tirosin dan triptofan) yaitu pada panjang gelombang $280 \mathrm{~nm}$. Selain itu, pemilihan panjang gelombang ini juga didasari oleh penelitian yang telah dilakukan oleh $\mathrm{Na} \mathrm{Li} \mathrm{dkk}$ (2011) tentang serapan ion triiodida berbanding waktu reaksi. Hasil penelitian menunjukan bahwa pada panjang gelombang $351 \mathrm{~nm}$ ion triiodida akan memberikan serapan yang maksimum walaupun reaksi telah berlangsung lebih dari 130 detik.

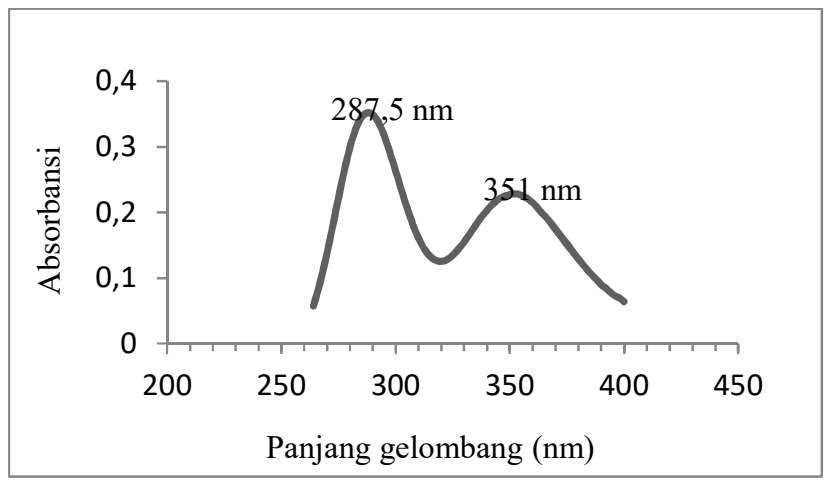

Gambar 1. Kurva panjang gelombang maksimum

\subsection{Optimasi Parameter Pengukuran}

Optimasi parameter pengukuran dilakukan terhadap konsentrasi asam fosfat $\left(\mathrm{H}_{3} \mathrm{PO}_{4}\right)$ dan kalium iodida (KI). Optimasi $\mathrm{H}_{3} \mathrm{PO}_{4}$ dan $\mathrm{KI}$ dilakukan agar diperoleh kondisi optimum pengukuran iodium. Optimasi terhadap $\mathrm{H}_{3} \mathrm{PO}_{4}$ dilakukan karena iodium $\left(\mathrm{I}_{2}\right)$ terbentuk dari hasil reaksi $\mathrm{KIO}_{3}$ dan $\mathrm{KI}$ dalam suasana asam. Selain itu, optimasi asam $\left(\mathrm{H}^{+}\right)$juga bertujuan untuk mengurangi pengaruh ion logam yang terdapat dalam sampel terhadap iodium serta mencegah terjadinya hidrolisis $\mathrm{I}_{2}$.

$$
\mathrm{I}_{2}+\mathrm{H}_{2} \mathrm{O} \rightleftarrows \mathrm{OI}^{-}+2 \mathrm{H}^{+}+\mathrm{I}^{-}
$$

Dari hasil optimasi, diperoleh konsentrasi optimum $\mathrm{H}_{3} \mathrm{PO}_{4}$ adalah 0,6 M (Gambar 2).

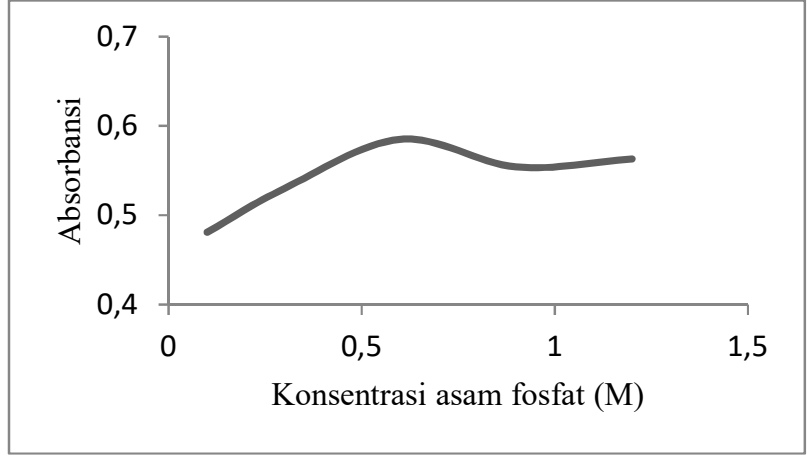

Gambar 2. Kurva optimasi asam fosfat

Dalam reaksi pembentukan iodium, KI berperan sebagai oksidator. $\mathrm{KI}$ akan mereduksi $\mathrm{KIO}_{3}$ menjadi $\mathrm{I}_{2}$. Selain itu, KI juga akan smelarutkan serta mencegah penguapan iodium yang telah terbentuk. Oleh sebab itu, perlu dilakukan optimasi terhadap konsentari KI yang akan digunakan untuk analisis kandungan iodium dalam rumput laut. Dari hasil optimasi, diperoleh kondisi optimum pengukuran yaitu pada konsentrasi KI 0,06 M (Gambar 3). 


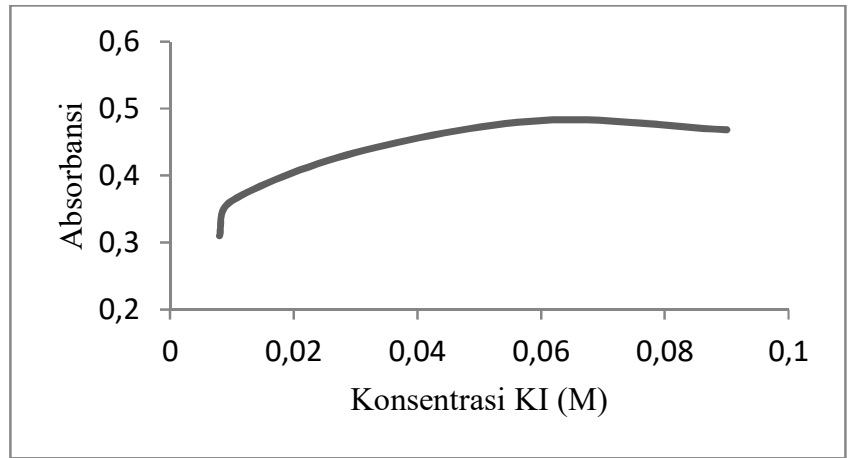

Gambar 3. Kurva optimasi kalium iodida.

\subsection{Pengukuran Kandungan Iodium Dalam Rumput Laut}

Hasil analisis kandungan iodium pada ketiga daerah sampel (Gambar 4) memiliki perbedaan, dimana kandungan iodium tertinggi terdapat pada rumput laut $e$. cottonii dari perairan Taar $(33,96 \mu \mathrm{g} / \mathrm{g})$ sedangkan rumput laut dari perairan Ohoidertawun $(27,01 \mu \mathrm{g} / \mathrm{g})$ dan $\operatorname{Wab}(28,91 \mu \mathrm{g} / \mathrm{g})$. Perbedaan kandungan iodium dalam rumput laut dapat terjadi akibat dari perbedaan kondisi perairan tempat pembudidayaan rumput laut $e$. cottonii. Penelitian Matanjun dkk (2009), terhadap kandungan nutrisi dalam beberapa jenis rumput laut diperairan Kalimantan Utara didapati bahwa kondisi perairan tempat pembudidayaan rumput laut sangat berpengaruh terhadap proses akumulasi iodium atau pun senyawa-senyawa lain yang terkandung dalam air laut. Dengan demikian, pola sirkulasi air laut (termasuk arus) pada suatu perairan akan berakibat pada tinggi dan rendahnya kandungan nutrisi, termasuk kandungan iodium dalam rumput laut.

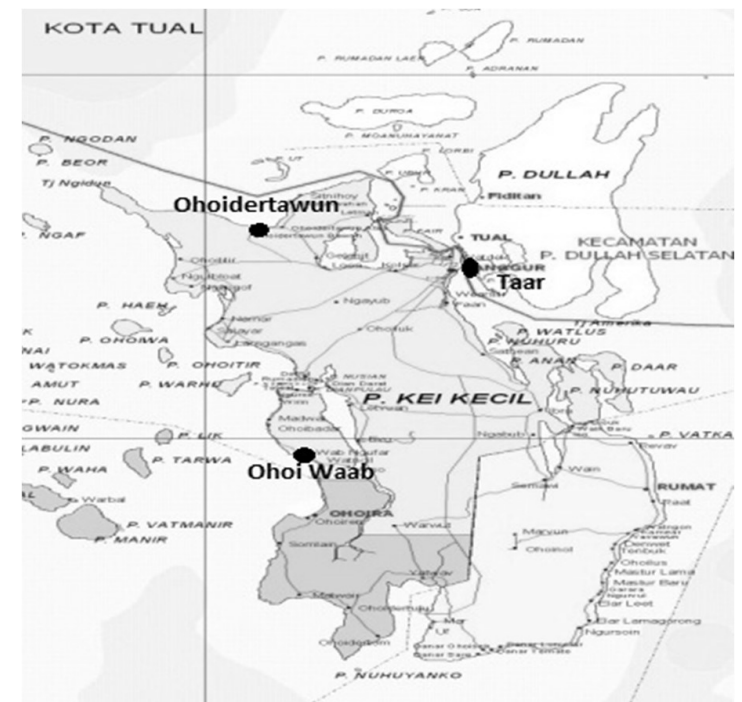

Gambar 4. Peta lokasi pengambilan sampel rumput laut.

Rata-rata kadar iodium dalam rumput laut e. cottonii yang dibudidayakan pada perairan Kei Kecil (29,96 $\mu \mathrm{g} / \mathrm{g}$ ) lebih tinggi bila dibandingkan dengan kandungan iodium rumput laut jenis yang sama yang dibudidayakan pada perairan Seram Timur dan Ambon - Maluku yaitu 6,3122 $\mu \mathrm{g} / \mathrm{g}$ dan 6,3293 $\mu \mathrm{g} / \mathrm{g}$ (Dulanlebit dan Hattu, 2009) serta rumput laut yang berasal dari perairan Kalimantan Utara yaitu $9 \mu \mathrm{g} / \mathrm{g}$ (Matanjun dkk, 2009). Kandungan iodium yang tinggi pada rumput laut e. cottonii yang dibudidayakan pada perairan Kepulauan Kei Kecil dapat dijadikan sebagai sumber bahan pangan untuk memenuhi kebutuhan asupan iodium. 


\section{Kesimpulan}

Berdasarkan hasil pengujian yang dilakukan rata-rata kandungan iodium dalam rumput laut e. cottonii yang dibudidayakan pada perairan Kei Kecil yaitu 29,96 $\mu \mathrm{g} / \mathrm{g}$. Kandungan iodium yang cukup tinggi dalam rumput laut e. cottonii yang dibudidayakan pada Perairan Kei Kecil dapat dijadikan sebagai sumber asupan iodium. Kedepannya perlu dilakukan penelitian terkait pemanfaatan rumput laut e. cottonii yang berasal dari perairan Kei Kecil sebagai bahan baku pembuat pangan olahan yang kaya iodium.

\section{Daftar Pustaka}

Adriani M, dan Wijadmadi B. 2012. Pengantar Gizi Masyarakat. Jakarta ; Kencana

Dulanlebit Y. H, and Hattu N. 2009. Bioconcentration Analysis of Iodate in Euheuma Cottonii Seaweed in Coastal Area of Ambon island and West Ceram As Alternative Food Sources of Iodine. Proc. International Seminar on Science and Technology - ISSTEC'09. Jogjakarta. Indonesia. Hal 399-403.

Gunanti I. R, Suhardjo, Kusharto C. M, Rimbawan, dan Wirjadwadi B. 1999. Kandungan Iodium pada Beberapa Bahan Makanan di Daerah Pantai endimik dan non-endemik. Buletin Penelitian Sistem Kesehatan. Volume 3 No 1: Hal 1-15

Jung S. H, Yeon J. W, Kang Y, and Song K. 2014. Determination of Triiodide Ion Concentration Using UVVisible Spectrophotometry. Asian J. Chem. Vol. 26, No. 13 : 4084-4086, http://dx.doi.org/10.14233/ajchem.2014.17720

Li N, Shi L, Wang X, Guo F, and Yan C. 2011. Experimental Study of Closed System in the Chlorine DioxideIodide-Sulfuric Acid Reaction by UV-Vis Spectrophotometric Method. International Journal of Analytical Chemistry. Volume 2011. Article ID 130102, 7 pages. doi:10.1155/2011/130102

Matanjun P, Mohamed S, Mustapha N. M, and Muhammad K. 2009. Nutrient Content Of Tropical Edible Seaweeds, Eucheuma Cottonii, Caulerpa Lentillifera And Sargassum Polycystum. J Appl Phycol., Volume 21 : 75-80. DOI 10.1007/s10811-008-9326-4 